\title{
Serumen Obsturan pada Siswa Sekolah Dasar di Tabanan, Bali
}

\author{
Cerumen obsturan in elementary school students in Tabanan, Bali \\ I Putu Yupindra Pradiptha ${ }^{1 *}$, Purnawan Budisetia ${ }^{2}$, Christy Adi Mukti \\ ${ }^{1}$ Spesialis THT-KL Klinik Utama Sari Dharma Denpasar \\ ${ }^{2}$ Yayasan Peduli Kemanusiaan \\ *Penulis korespondensi. I Putu Yupindra Pradiptha. Email: putuyupindra@gmail.com
}

\begin{abstract}
ABSTRAK
Latar Belakang: Serumen yang menumpuk merupakan alasan utama saluran telinga bisa tersumbat. Permasalahan THT pada siswa usia sekolah dasar harus mendapat perhatian yang serius karena akan mempengaruhi proses pendidikan di sekolah. Penelitian ini bertujuan untuk mengetahui jumlah kasus serumen obsturan yang terdapat pada siswa usia sekolah dasar di Tabanan, Bali.

Metode: Penelitian menggunakan rancangan penelitian deskriptif cross sectional. Penelitian dilakukan di 12 sekolah dasar di Kabupaten Tabanan, Bali. Penelitian dilakukan mulai bulan Januari-Desember 2019. Subjek penelitian diambil dari siswa sekolah dasar dari kelas 1 sampai kelas 6. Pengambilan sampel dilakukan dengan cara total sampling.

Hasil: Jumlah sampel siswa laki-laki 760 sampel (55.6\%) dan siswa perempuan 606 sampel (44.4\%). Usia yang terbanyak adalah 12 tahun (19.6\%) sedangkan yang paling sedikit adalah 6 tahun $(2.1 \%)$. Permasalahan serumen obsturan terdapat pada 499 sampel (36.5\%). Letak serumen yang terbanyak adalah bilateral (55.5\%).

Kesimpulan: Serumen obsturan merupakan permasalahan yang cukup tinggi pada siswa usia sekolah dan dapat mengganggu proses kegiatan belajar mengajar.
\end{abstract}

Kata kunci: serumen, sekolah dasar, siswa

\begin{abstract}
Background: Accumulated wax is the main reason the ear canal can become blocked. ENT problems in elementary school students should receive serious attention because it will affect the education process in schools. This study aims to determine the number of cases of cerumen obsturan in elementary school in Tabanan, Bali.

Methods: This study used a cross sectional descriptive study design. The research was conducted in 12 elementary schools in Tabanan Regency, Bali. The research was conducted from January to December 2019. The research subjects were taken from elementary school students from grade 1 to grade 6. Sampling was done by total sampling.

Results: The number of samples of male student was 760 samples (55.6\%) and female student was 606 samples (44.4\%). The highest age was 12 years (19.6\%) while the lowest was 6 years (2.1\%). Cerumen obsturan problems were found in 499 samples (36.5\%). Most of the cerumen was bilateral (55.5\%).

Conclusion: Obstacle serum is a problem that is quite high in school age students and can interfere with the process of teaching and learning activities
\end{abstract}

Keywords: cerumen, elementary school, students 


\section{PENDAHULUAN}

Serumen atau kotoran telinga adalah cairan yang diproduksi pada liang telinga yang berfungsi membersihkan, melindungi, dan melumasi saluran pendengaran eksternal. Serumen yang menumpuk merupakan alasan utama saluran telinga bisa tersumbat. Meskipun seringkali tidak berbahaya, penyumbatan saluran telinga oleh serumen dapat menyebabkan sejumlah gejala: gangguan pendengaran, tinitus, rasa penuh, gatal, otalgia, keluarnya cairan, bau, dan

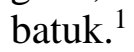

Permasalahan THT pada siswa usia sekolah dasar harus mendapat perhatian yang serius karena akan mempengaruhi proses pendidikan di sekolah. Siswa usia sekolah dasar dapat terganggu proses belajarnya apabila terdapat permasalahan di bidang THT. Sehingga secara otomatis akan mengurangi daya tangkap dan daya serap siswa dalam menerima materi yang diajarkan. ${ }^{2}$

Penelitian ini bertujuan untuk mengetahui jumlah kasus serumen obsturan yang terdapat pada siswa usia sekolah dasar di Tabanan, Bali. Mengetahui permasalahan THT khususnya serumen obsturan menjadi penting karena dapat digunakan sebagai acuan untuk melakukan intervensi yang tepat untuk mengatasi permasalahan pendengaran sejak usia dini.

\section{METODE}

Penelitian ini menggunakan rancangan penelitian deskriptif cross sectional. Penelitian dilakukan di 12 sekolah dasar di Kabupaten Tabanan, Bali. Penelitian dilakukan mulai bulan Januari-Desember 2019. Subjek penelitian diambil dari siswa sekolah dasar dari kelas 1 sampai kelas 6 yang dilakukan saat pelaksanaan bakti sosial Yayasan Peduli Kemanusiaan yang didukung Inspirasia Foundation. Subjek penelitian diperiksa oleh dokter spesialis THT-KL. Pemeriksaan dilakukan dengan alat otoskop. Pengambilan sampel dilakukan dengan cara total sampling yaitu setiap penderita yang memenuhi kriteria inklusi penelitian dimasukkan dalam sampel penelitian. Kriteria inklusi yaitu seluruh siswa yang hadir pada saat bakti sosial. Hasil penelitian dianalisis dan disajikan secara deksriptif dalam bentuk tabel dan narasi.

\section{HASIL DAN PEMBAHASAN}

\section{Hasil}

Penelitian dilakukan di 12 sekolah dasar di Kabupaten Tabanan, Bali. Penelitian ini melibatkan 1366 sampel dengan jumlah sampel lelaki 760 sampel (55.6\%) dan perempuan 606 sampel (44.4\%). Usia yang terbanyak adalah 12 tahun (19.6\%) sedangkan yang paling sedikit adalah 6 tahun (2.1\%). Permasalahan serumen obsturan terdapat pada 499 sampel $(36.5 \%)$. Letak serumen yang terbanyak adalah bilateral (55.5\%). Distribusi sampel penelitian ditampilkan pada table 1 sampai table 4.

\section{Pembahasan}

Permasalahan THT pada siswa usia sekolah dasar harus mendapat perhatian yang serius karena akan mempengaruhi proses pendidikan di sekolah karena dapat mengganggu proses kegiatan belajar mengajar. $^{2}$

Hasil penelitian ini didapatkan jumlah sampel lelaki 760 sampel (55.6\%) dan perempuan 606 sampel (44.4\%). Usia yang terbanyak adalah 12 tahun (19.6\%) sedangkan yang paling sedikit adalah 6 tahun (2.1\%). Permasalahan serumen obsturan terdapat pada 499 sampel $(36.5 \%)$. Letak serumen yang terbanyak adalah bilateral (55.5\%). Pada penelitian serupa di Tanzania didapatkan dari 406 peserta, sembilan puluh lima $(23,4 \%)$ mengalami serumen obsturan dengan 56 peserta $(58,9 \%)$ adalah laki-laki dan 39 peserta $(41,1 \%)$ adalah perempuan. Impaksi serumen ditemukan di telinga bilateral pada $55(57,9 \%)$ pasien. ${ }^{3}$ Penelitian di Ghana yang melibatkan 4407 siswa-siswi berusia antara 5 sampai 16 
tahun di 11 sekolah dasar pemerintah didapatkan serumen obsturan ditemukan pada $988(22,4 \%)$ siswa. $^{4}$

Tabel. 1 Distribusi sampel penelitian berdasarkan jenis kelamin.

\begin{tabular}{lcc}
\hline \multicolumn{1}{c}{ Jenis Kelamin } & $\mathrm{n}$ & $\%$ \\
\hline Lelaki & 760 & 55,6 \\
Perempuan & 606 & 44,4 \\
\hline \multicolumn{1}{c}{ Jumlah } & 1366 & 100 \\
\hline
\end{tabular}

Tabel. 2 Distribusi sampel penelitian berdasarkan usia

\begin{tabular}{ccc}
\hline Usia & $\mathrm{n}$ & $\%$ \\
\hline 6 & 28 & 2,1 \\
7 & 196 & 14,3 \\
8 & 190 & 13,9 \\
9 & 197 & 14,4 \\
10 & 241 & 17,6 \\
11 & 247 & 18,1 \\
12 & 267 & 19,6 \\
\hline Total & 1366 & 100 \\
\hline
\end{tabular}

Tabel. 3 Distribusi sampel penelitian berdasarkan diagnosis

\begin{tabular}{ccc}
\hline Kondisi & $\mathrm{n}$ & $\%$ \\
\hline Serumen obsturan & 499 & 36,5 \\
Tidak terdapat serumen & 867 & 63,5 \\
\hline Jumlah & 1366 & 100 \\
\hline
\end{tabular}

Tabel. 4 . Distribusi sampel penelitian berdasarkan letak serumen

\begin{tabular}{ccc}
\hline Letak & $\mathrm{n}$ & $\%$ \\
\hline Unilateral & 222 & 44,5 \\
Bilateral & 277 & 55,5 \\
\hline Jumlah & 499 & 100 \\
\hline
\end{tabular}

Penelitian lainnya di Nigeria didapatkan tiga ratus satu $(47,8 \%)$ adalah perempuan dan tiga ratus dua puluh sembilan $(52,2 \%)$ adalah laki-laki. Serumen obsturan memiliki prevalensi $46,7 \%$ dan secara signifikan lebih tinggi pada murid dengan status sosial ekonomi bawah $(\mathrm{p}=0,036) .{ }^{5}$ Kelompok usia 1 20 tahun merupakan yang paling banyak terkena $(29,3 \%)$ dari 239 pasien di Nigeria. Keluhan utama adalah gangguan pendengaran 
dalam 120 kasus. Kedua telinga sebagian besar terpengaruh pada $48,5 \%$ pasien. ${ }^{6}$ Beberapa hasil penelitian diatas menunjukkan angka kejadian serumen obsturan cukup tinggi di luar Indonesia.

Penyakit telinga merupakan masalah kesehatan masyarakat yang terabaikan karena kurangnya dokter maupun spesialis THT di pedesaan pada negara-negara berkembang. ${ }^{7}$ Penelitian di Indonesia didapatkan gangguan pendengaran pada siswa semakin banyak ditemukan di masyarakat terutama pada masyarakat kalangan menengah kebawah. Rendahnya pengetahuan dan keadaan ekonomi yang tidak memadai menambah panjang keluhan keluhan yang didapat dan diterima oleh puskesmas dan rumah sakit daerah. Gangguan pendengaran belum begitu mendapat perhatian serius dari masyarakat karena gejalanya tidak tampak dari luar. Penelitian di SD Negeri Negeri Baja Kuning Kecamatan Tanjung Pura didapatkan 11 murid yang menderita serumen obsturan. Temuantemuan terkait serumen obsturan pada siswasiswi sekolah ini diharapkan dapat memberi landasan untuk dilakukannya pemeriksaan rutin minimal serahun sekali untuk siswa-siswi sekolah terutama sekolah dasar. ${ }^{8}$ Penelitian lain di Sekolah dasar Negeri Tomang 03 Pagi dan Tomang 05 Pagi pada bulan Oktober November 2014, didapatkan temuan pemeriksaan otoskopi serumen obsturan $(51,2 \%)$ merupakan temuan pemeriksaan otoskopi terbanyak pada penelitian ini. ${ }^{10}$

Proporsi kejadian serumen obsturan lainnya pada siswa kelas 1 Sekolah dasar di wilayah pesisir (wilayah kerja Puskesmas Bandarharjo, Semarang Utara) adalah lebih dari setengah jumlah sampel yang diperiksa, yaitu sebesar $(50,8 \%)$. Berdasarkan keadaan tersebut, khususnya siswa sekolah di daerah pesisir memerlukan perhatian khusus, antara lain melakukan upaya kuratif dan rehabilitatif, dengan melakukan deteksi dini dan pengobatan kejadian impaksi serumen secara optimal untuk mencegah gangguan pendengaran. ${ }^{9}$ Penelitian lain tentang karakteristik pasien penyakit telinga eksternal yang berobat di Rumah Sakit Umum Wahidin
Sudirohusodo pada periode Januari hingga Desember 2012, dapat disimpulkan bahwa insidensi penyakit telinga luar selama periode Januari-Desember 2012 adalah 9,5\%. Distribusi penyakit telinga luar berdasarkan usia sebagian besar kelompok usia terbesar> 50 tahun sebanyak 214 kasus $(21,7 \%)$ dari total 984 pasien. ${ }^{11}$ Beberapa hasil penelitian di atas menunjukkan angka kejadian serumen obsturan cukup tinggi di Indonesia. Hal ini akan mengganggu proses belajar mengajar dan mempengaruhi perkembangan belajar siswa.

\section{KESIMPULAN}

Permasalahan serumen obsturan terdapat pada 499 sampel (36.5\%). Letak serumen obsturan yang terbanyak adalah bilateral (55.5\%). Serumen obsturan merupakan permasalahan yang cukup tinggi pada siswa usia sekolah dan dapat mengganggu proses kegiatan belajar mengajar.

\section{SARAN}

Perlu dilakukan follow up terhadap siswa usia sekolah dasar yang mengalami serumen obsturan agar kebersihan telinga tetap terjaga.

\section{UCAPAN TERIMA KASIH}

Ucapan terima kasih kepada Inspirasia Foundation yang telah mensupport kegiatan bakti sosial Yayasan Peduli Kemanusiaan

\section{DAFTAR PUSTAKA}

1. Schwartz SR, Magit AE, Rosenfeld RM, Ballachanda BB, Hackell JM, Krouse HJ, et.al. Clinical practice guideline (update): earwax (cerumen impaction). Otolaryngology-Head and Neck Surgery. 2017;156(1): 1-29.

2. Widiyanto P, Mulyaningsih EL, Pengaruh pengambilan serumen terhadap peningkatan prestasi belajar pada siswa sekolah dasar di wilayah kerja puskesmas mertoyudan I kabupaten magelang. 
Journal of Holistic Nursing Science. 2015;2(1): 10-18.

3. Mabenda SB, Bunabe G, Gilyoma JM, Chalya PL, Mahalu W. Prevalence of cerumen impaction and associated factors among primary school children in mwanza city, tanzania. Tanzania Journal of Health Research. 2019;21(1): 1-9.

4. Akotey SC, Adza EK, Awini A, Cobbinah JB, Darko K, Ador EW, et.al. Significance of ear wax impaction in school children: a case of winneba west circuit, ghana. Journal of Health, Medicine and Nursing. 2017;35: 86-91.

5. Eziyi JAE, Amusa YB, Nwawolo CC, Ezeanolue BC. Wax impaction in nigerian school children. East and Central African Journal of Surgery. 2011;16 (2): 40-45.

6. Gabriel OT. Cerumen impaction: challenges and management profile in a rural health facility. Niger Med J. 2015;56(6): 390-393.

7. Kumar R, Dhingra MK, Rani B, Mahen A, Singh MGPK. Ear wax of cerumen and its management strategies in a rural community of panipat, haryana. International Journal of Scientific Research. 2019;8(10): 78-79.
8. Lubis HML, Siregar SM. Program bersihbersih telinga (bbt) siswa sekolah dasar negeri kecamatan tanjung pura guna meningkatkan kualitas pendengaran dan pembelajaran. Jurnal Prodikmas: Hasil Pengabdian Masyarakat. 2018;2(2): 112117.

9. Najwati H, Saraswati DL, Muyassaroh. Gambaran pengetahuan orang tua dan perilaku membersihkan liang telinga anak dengan kejadian impaksi serumen pada anak sekolah dasar di wilayah pesisir (studi kasus pada anak kelas 1 di lima sekolah dasar, wilayah kerja puskesmas bandarharjo, semarang utara). Jurnal Kesehatan Masyarakat (e-Journal). 2017;5(4): 359-367

10. Taba JAP, Amalia M. Prevalensi gangguan pendengaran pada siswa-siswi kelas 4, 5, 6 sekolah dasar negeri tomang 03 pagi dan tomang 05 pagi, jakarta barat, tahun 2014. Tarumanagara Medical Journal. 2018;1(1): 122-127.

11. Pratiwi UM, Syahrijuita, Ramadhany S. Karakteristik penyakit telinga luar di makassar sulawesi selatan. Alami Journal. 2018;2(1): 28-36 